\title{
IMPLEMENTASI CASE-BASED REASONING PADA PEMANGGILAN SURAT AL QURAN UNTUK PENYANDANG DISABILITAS TANGAN BERBASIS ANDROID
}

\author{
Rentia Ayu Suprapto ${ }^{1}$, Mungki Astiningrum ${ }^{2}$, Ridwan Rismanto ${ }^{3}$ \\ Jurusan Teknologi Informasi, Program Studi Teknik Informatika,Politeknik Negeri Malang \\ ${ }^{1}$ rentiagaynela@gmail.com, ${ }^{2}$ mama.zahra@gmail.com ${ }^{3}$ ridwan@polinema.ac.id
}

\begin{abstract}
Abstrak
Penelitian ini bertujuan untuk mengetahui pengaruh intensitas suara menggunakan command voice terhadap respon aplikasi pada perangkat smartphone berbasis android. Dimana suara yang memiliki kemiripan terhadap data yang ingin dipanggil dapat digolongkan dengan data yang terdapat pada aplikasi.

Penelitian ini merupakan penelitian korelasi, menggunakan metode Case-Based Reasoning (CBR) dengan menghitung masing-masing huruf pada setiap kata yang diucapkan dengan kata yang sudah ada pada aplikasi. CBR merupakan salah satu metode yang menggunakan pendekatan kecerdasan buatan (Artificial intelligent) dan menitik beratkan pemecahan masalah dengan didasarkan pada knowledege dari kasus-kasus yang sudah ada. Kasus-kasus yang diperoleh dari nama surat Al Quran yang sudah ada. Sedangkan untuk memberikan bobot pada huruf menggunakan metode nearest neighbor, dimana yang sering muncul lah yang memiliki bobot terbesar.

Hasil dari penelitian ini memberikan keluaran berupa tampilan surat Al Quran yang memiliki persentase paling besar sehingga bisa dikatagorikan memiliki kemiripan yang paling dekat. Nilai kedekatan dari 5 kasus lama terdapat kasus baru dari inputan suara Al Fatekah didapat 0,9655172413 terhadap Al Fatihah, 0,3793103448 terhadap Al Furqan, 0,7241379310 terhadap Al Fath, 0,3793103448 terhadap Al Fil, dan 0,5517241379 terhadap Al Falaq.
\end{abstract}

Kata kunci : Case-Based Reasoning, nearest neighbor, command voice, Knowledge Based System

\section{Pendahuluan}

Difabel atau disabilitas adalah istilah yang meliputi gangguan, keterbatasan, dan pembatasan partisipasi. Pada umumnya seseorang penyandang disabilitas dianggap sebagai seseorang yang tidak mampu melakukan apapun seperti orang normal yang mampu melakukan segalanya, namun dengan diberikan kesempatan yang sama untuk berkembang sebagaimana orang normal lainnya, seseorang penyandang disabilitas berpotensi untuk menjalani kehidupan secara penuh dan berkontribusi pada vitalitas sosial, budaya, dan ekonomi dari masyarakat mereka. Pada dasarnya seseorang penyandang disabilitas tangan bukanlah seseorang yang tidak memiliki tangan, namun mereka yang tidak bisa menggunakan fungsi tangan secara normal, baik karena kecelakaan maupun bawaan dari lahir. Penyandang disabilitas tangan seringkali kesulitan melakukan aktifitas seperti makan, mencuci, minum, dan lain-lain. Mereka menggunakan anggota tubuh lain sebagai pengganti fungsi tangan mereka.

Islam merupakan agama yang sering dianut oleh masyarakat Indonesia, dimana $\mathrm{Al}$ Qur'an merupakan kitab suci yang wajib dibaca oleh pemeluk agama islam. Namun di Indonesia cara mengucapkan kata (aksen) atau lekuk lidah memiliki aksen kata yang berbeda sesuai dengan asal daerah ataupun suku bangsa. Logat dapat mengidentifikasi lokasi di mana pembicara berada dan lain-lain. Sehingga logat dalam membaca Al Qur'an masing-masing orang sering kali berbeda.

Perkembangan teknologi informasi saat ini sudah merambah ke berbagai sisi kehidupan manusia. Salah satu teknologi yang sering digunakan saat ini adalah smartphone berbasis android, beragam aplikasi free content diciptakan untuk memenuhi kebutuhan sekaligus sebagai daya tarik tersendiri bagi pengguna android.

Misalnya saja penggunaan aplikasi Al Qur'an digital.

Penggunaan aplikasi Al Qur'an digital memang tidak begitu sulit, pengguna smartphone android dapat mengunduhnya secara langsung lewat playstore. Namun Al Qur'an digital yang terdapat pada playstore pada umumnya menggunakan sentuhan, sedangkan bagi penyandang disabilitas tangan masih mengalami kesulitan karena penggunaannya dengan cara disentuh. Oleh karena itu, penulis membuat aplikasi Al Qur'an Digital Berbasis command voice (perintah suara) untuk memudahkan penyandang disabilitas tangan dalam membaca kitab suci Al Qur'an. Dimana pemanggilan nama surat menggunakan metode Case-Based Reasoning(CBR) untuk meminimalkan 
kesalahan pengucapan yang terjadi. Keberadaan sistem ini diharapkan dapat membantu masyarakat penyandang disabilitas tangan dalam membaca

Al Qur'an tanpa memperhitungkan logat masingmasing daerah.

\section{Metodologi Penelitian}

Alat dan bahan yang digunakan untuk pembuatan aplikasi Al Qur'an digital berbasis command voice untuk penyandang disabilitas tangan adalah sebagai berikut :

Tabel 1. Spesifikasi perangkat yang digunakan

\begin{tabular}{|c|c|c|c|}
\hline No & Perangkat & Spesifikasi & Jumlah \\
\hline 1 & Smartphone & Berbasis Android & 1 unit \\
\hline 2 & $\begin{array}{c}\text { Laptop atau } \\
\text { PC }\end{array}$ & Processor Core i3 & 1 unit \\
\hline & & $\begin{array}{c}\text { RAM DDR3 } 2 \\
\text { GB }\end{array}$ & \\
\hline 3 & Kabel USB & & 1 unit \\
\hline 4 & $\begin{array}{c}\text { Android } \\
\text { Studio }\end{array}$ & & $\begin{array}{c}1 \\
\text { perangkat }\end{array}$ \\
\hline 5 & Google API & Command voice & $\begin{array}{c}1 \\
\text { perangkat }\end{array}$ \\
\hline
\end{tabular}

\subsection{Metode Perancangan Aplikasi}

Dalam penilisan bab ini akan membahas mengenai metode serta perancangan yang akan digunakan dan diterapkan dalam penelitian ini.

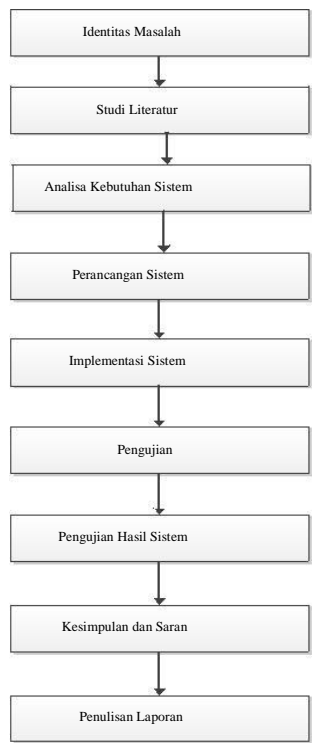

Gambar 1. Diagram alur metodologi penelitian

\subsection{Metode Case-Based Reasoning}

Aplikasi ini merupakan aplikasi yang bertujuan untuk mencari nama surat namun akan memperbaiki pengucapan yang salah dengan nama surat yang terdapat didalam database. Metode String Matching memiliki kekurangan dalam mendukung penyelesaian kasus/permasalahan yang bersifat samar atau dengan level kemiripan yang tidak $100 \%$ terhadap informasi yang disimpan. Untuk itu diperlukan sistem yang lebih fleksibel yang dapat mendukung hal tersebut. Dalam tulisan ini diterapkan metode Case-Based Reasoning dengan Algoritma Nearest Neighbor untuk mendukung penyelesaian kasus/ permasalahan berdasarkan kasus/permasalahan yang sudah ada.

\subsubsection{Siklus Metode Case-Base Reasoning}

Aamodt dan Plaza (1994) menggambarkan tipe $C B R$ sebagai suatu proses melingkar seperti pada gambar 1 yang terdiri dari 4 RE yaitu:

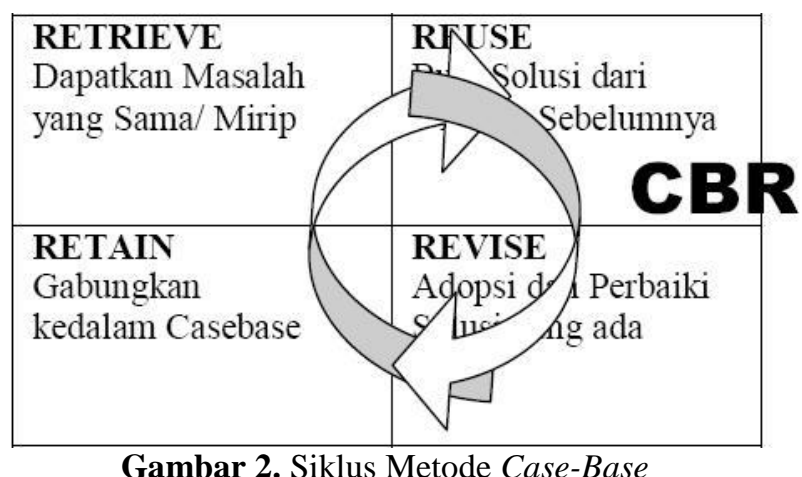

Reasoning

\section{a. Retrieve}

Retrieve adalah proses memperoleh kasus-kasus yang mirip untuk dibandingkan dengan kumpulan kasus-kasus dimasa lalu. Proses ini dimulai dengan tahapan pengenalan masalah dan berakhir ketika kasus yang ingin dicari solusinya telah ditemukan kemiripannya dengan kasus yang telah ada.

\section{b. Reuse}

Reuse adalah proses penggunaan kembali kasuskasus yang dan (kasus masa lalu) yang digunakan untuk mencari solusi dari masalah baru (masalah sekarang).

c. Revise

Revise adalah proses merubah dan memperbaiki solusi yang diusulkan, jika diperlukan.

\section{d. Retain}

Retain adalah menyimpan pengetahuan yang nantinya akan digunakan untuk memecahkan masalah kedalam basis kasus yang ada. Pada proses ini tetap menggunakan solusi yang terakhir sebagai bagian dari kasus baru. 


\subsubsection{Metode Nearest Neighbor}

Proses dalam CBR dapat menggunakan berbagai teknik, diantaranya adalah algoritma nearest neighbor untuk menghitung tingkat kemiripan (jarak) suatu kasus terhadap kasus lain berdasarkan beberapa atribut yang didefinisikan berdasar pembobotan tertentu dan kemudian tingkat kemiripan (jarak) dari keseluruhan atribut akan dijumlahkan.

Algoritma nearest neighbor merupakan pendekatan untuk mencari kasus dengan kedekatan antara kasus baru dengan kasus lama, yaitu berdasarkan pada kecocokan bobot sejumlah fitur yang ada (Kusrini, 2009). Metode ini mencari jarak terhadap tujuan dari data yang telah disimpan sebelumnya. Setelah didapatkan jaraknya kemudian dicari jarak terdekat. Jarak terdekat tersebut yang digunakan untuk mencari identitas tujuan.

Adapun rumus yang digunakan dalam perhitungan kedekatan (similarity) adalah sebagai berikut:

$$
\text { Perhitungan }=\frac{S_{1} * W_{1}+S_{2} * W_{2}+\cdots+S_{n} * W_{n}}{W_{1}+W_{2} W_{1}+\cdots+W_{n}}
$$

Gambar 3 Rumus untuk perhitungan dengan nearest neighbour

Keterangan:

$\mathrm{s}=$ similarity (nilai kemiripan)

$\mathrm{w}=$ weight (bobot yang diberikan.

\subsection{Rancangan Sistem}

\subsubsection{Arsitektur Sistem}

Perancangan arsitektur sistem adalah tahap penulis dalam merancang suatu sistem yang diperlukan untuk memenuhi kebutuhan fungsional aplikasi. Tujuan dari perancangan sistem adalah untuk memenuhi kebutuhan user mengenai gambaran yang jelas tentang perencanaan yang akan di buat serta diimplementasikan.

Metode cased-based reasoning merupakan metode yang menerapkan 4 tahapan proses, yaitu retrieve, reuse, revise, dan retain. Cara kerja sistem secara umum berpedoman pada basis pengetahuan yang sudah ada kemudian dihitung tingkat kemiripannya dengan kasus baru yang dimasukan pengguna. Berdasarkan tingkat kemiripan kasus inilah sistem akan mengeluarkan nilai persentase jarak kemiripan antar nama surat, dimana yang memiliki persentase paling besarlah yang akan dianggap mirip.

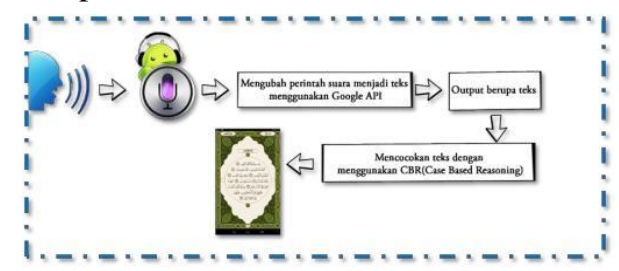

Gambar 4. Arsitektur Sistem Al Quran Digital
Proses kerja yang terdapat pada aplikasi Al Qur'an untuk disabilitas tangan terdapat pada Smartphone android. Cara kerja aplikasi Al Qur'an untuk disabilitas tangan ini adalah dengan menngunakan microphone sebagai alat bantu memanggil nama surat sehingga tidak terdapat noise pada kata yang diinputkan. Selanjutnya, keluaran suara dari microphone tersebut akan diolah menggunakan bantuan command voice dari Google API untuk dikirim ke server cloud milik google. Kemudia kata yang telah diinputkan tersebut akan diolah menggunakan metode Case-Based Reasoning(CBR) untuk menentukan jarak terdekat dari kata yang diinputkan dengan kata yang terdapat pada data Al Qur'an.

Cara kerja sistem secara umum berpedoman pada basis pengetahuan yang dimiliki oleh sistem yang bersumber dari data yang telah ada dan telah diteliti kebenarannya, yang kemudian dihitung tingkat kemiripan kasus lama dengan kasus baru yang dimasukan oleh pengguna. Berdasarkan tingkat kemiripan kasus inilah, sistem akan mengeluarkan nama surat yang diinginkan oleh pengguna.

\subsubsection{Analisa Sistem}

a. Proses penerapan metode Nearest Neighbor (NN) pada Case-Based Reasoning (CBR)

Proses penerapan metode Nearest Neighbor (NN) pada Case-Based Reasoning(CBR) yaitu dengan mencari kemiripan kasus lama dengan kasus baru. Pencarian kemiripan antara kasus baru dengan kasus lama dilakukan dengan cara mencocokan nama surat yang diinputkan oleh mengguna dengan nama surat yang ada pada basis pengetahuan. Pada proses Retrieve ini akan dilakukan pembobotan dengan metode Nearest Neighbor Retrieve.

Misalnya ucapkan kata $=$ Al Fatikah

\section{Perhitungan Kasus 1:}

Mengelompokan kata yang memiliki huruf kesatu, kedua, dan ketiga yang sama dengan $\mathrm{Al}$ Fatihah itu artinya A, L, F:

Tabel 2. Jumlah Bobot Al Fatihah

\begin{tabular}{|l|l|l|l|l|l|l|l|l|l|l|l|}
\hline AL FATIKAH & 5 & & 5 & 1 & 5 & 5 & 1 & 1 & 5 & 1 & $\begin{array}{c}\text { Jumlah } \\
29\end{array}$ \\
\hline
\end{tabular}


Tabel 3. Perhitungan Kasus 1

\begin{tabular}{|c|c|c|}
\hline Kasus Baru & Nilai & Kasus Lama \\
\hline A & 1 & A \\
\hline L & 1 & L \\
\hline F & 1 & F \\
\hline A & 1 & A \\
\hline T & 1 & T \\
\hline I & 1 & I \\
\hline K & 0 & H \\
\hline A & 1 & A \\
\hline H & 1 & H \\
\hline
\end{tabular}

Perhitungan $=\frac{S_{1} * W_{1}+S_{2} * W_{2}+\cdots+S_{n} * W_{n}}{W_{1}+W_{2} W_{1}+\cdots+W_{n}}$

Perhitungan kedekatan $=$

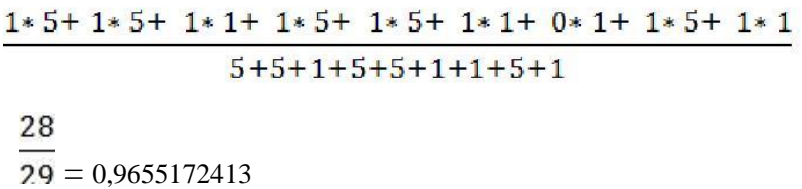

\section{Perhitungan Kasus 2:}

Tabel 4. Perhitungan Kasus 2

\begin{tabular}{|c|c|c|}
\hline Kasus Baru & Nilai & Kasus Lama \\
\hline A & 1 & A \\
\hline L & 1 & L \\
\hline F & 1 & F \\
\hline A & 0 & U \\
\hline T & 0 & R \\
\hline I & 0 & Q \\
\hline K & 0 & A \\
\hline A & 0 & N \\
\hline H & 0 & \\
\hline
\end{tabular}

Perhitungan kedekatan $=$

$$
\begin{aligned}
& \frac{1 * 5+1 * 5+1 * 1+0 * 5+0 * 5+0 * 1+0 * 1+0 * 5+0 * 1}{5+5+1+5+5+1+1+5+1} \\
& \frac{11}{29}=0,3793103448
\end{aligned}
$$

Perhitungan Kasus 3:

Tabel 5. Perhitungan Kasus 3

\begin{tabular}{|c|c|c|}
\hline Kasus Baru & Nilai & Kasus Lama \\
\hline A & 1 & A \\
\hline L & 1 & L \\
\hline F & 1 & F \\
\hline A & 1 & A \\
\hline T & 1 & T \\
\hline I & 0 & H \\
\hline K & 0 & \\
\hline A & 0 & \\
\hline H & 0 & \\
\hline
\end{tabular}

Perhitungan kedekatan $=$

$$
\begin{aligned}
& \frac{1 * 5+1 * 5+1 * 1+1 * 5+1 * 5+0 * 1+0 * 1+0 * 5+0 * 1}{5+5+1+5+5+1+1+5+1} \\
& \frac{21}{29}=0,7241379310
\end{aligned}
$$

\section{Perhitungan Kasus 4:}

Tabel 6. Perhitungan Kasus 4

\begin{tabular}{|c|c|c|}
\hline Kasus Baru & Nilai & $\begin{array}{c}\text { Kasus } \\
\text { Lama }\end{array}$ \\
\hline A & 1 & A \\
\hline L & 1 & L \\
\hline F & 1 & F \\
\hline A & 0 & I \\
\hline T & 0 & L \\
\hline I & 0 & \\
\hline K & 0 & \\
\hline A & 0 & \\
\hline H & 0 & \\
\hline
\end{tabular}

Perhitungan kedekatan $=$

$$
\begin{aligned}
& \frac{1 * 5+1 * 5+1 * 1+0 * 5+0 * 5+0 * 1+0 * 1+0 * 5+0 * 1}{5+5+1+5+5+1+1+5+1} \\
& \frac{11}{29}=0,3793103448
\end{aligned}
$$

\section{Perhitungan Kasus 5:}

Tabel 7. Perhitungan Kasus 5

\begin{tabular}{|c|c|c|}
\hline Kasus Baru & Nilai & Kasus Lama \\
\hline A & 1 & A \\
\hline L & 1 & L \\
\hline F & 1 & F \\
\hline A & 1 & A \\
\hline T & 0 & L \\
\hline I & 0 & A \\
\hline K & 0 & Q \\
\hline A & 0 & \\
\hline H & 0 & \\
\hline
\end{tabular}

Perhitungan kedekatan=

$$
\begin{aligned}
& \frac{1 * 5+1 * 5+1 * 1+1 * 5+0 * 5+0 * 1+0 * 1+0 * 5+0 * 1}{5+5+1+5+5+1+1+5+1} \\
& \frac{16}{29} \quad 1.0,5517241379
\end{aligned}
$$

b. Melakukan Proses Reuse (Mencari Solusi dari Masalah Baru)

Menentukan bobot paling tinggi pada kasus diatas. Selain itu hasil perhitungan dengan bobot menunjukan lebih dari $91 \%$, jadi solusi kasis1 lah yang ditampilkan kepada pengguna.

Tabel 8. Hasil Perhitungan

\begin{tabular}{|c|c|c|}
\hline Ranking & Bobot Kemiripan & Nama Surat \\
\hline 1 & 0,09655172413 & Al Fatihah \\
\hline 2 & 0,7241379310 & Al Fath \\
\hline 3 & 0,5517241379 & Alfalaq \\
\hline 4 & 0,3793103448 & Al Fil \\
\hline 5 & 0,3793103448 & Al Furqan \\
\hline
\end{tabular}


Pada proses Reuse, solusi yang diberikan adalah solusi dengan bobot kemiripan kasus baru dengan kasus lama yang paling tinggi, dalam kasus ini adalah kasus no 1 yaitu Al Faihah. Hasil perhitungan dengan bobot menunjukan tingkat kedekatan lebih dari $91 \%$, jadi solusi kasus no 1 lah yang akan ditampilkan kepada pengguna.

\section{c. Proses Revise}

Lalu melalui tahap Revise yaitu proses peninjauan kembali kasus dan solusi yang diberikan jika pada proses Retrieve, system tidak dapat memberikan hasil yang tepat. Pada contoh kasus Al Fatikah sudah menghasilkan solusi dengan tingkat kepercayaan $91 \%$, jadi solusi yang dihasilkan dapat langsung diberikan.

\section{d. Proses Retain}

Setelah proses Revise selesai dan sudah ditemukan solusi yang benar maka aplikasi mulai menyimpan hasil perhitungan dari keseluruhan proses pemanggilan.

\section{Hasil dan Pembahasan}

\subsection{Halaman Utama}

Halaman Utama dari Al Qur'an digital untuk penyandang disabilitas tangan ini berisi tentang cara penggunaan aplikasi yang benar, dimana terdapat tutorial cara penggunaan serta kata yang dapat diucapkan pada aplikasi ini.

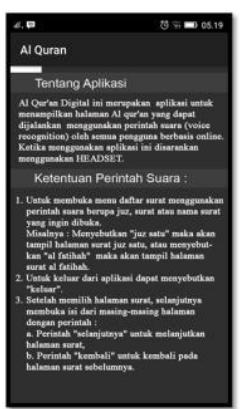

Gambar 5. Halaman Utama

\subsection{Halaman Algoritma}

Halaman Algoritma ini merupakan hasil perhitungan dari jarak antara kata yang diucapkan dengan data yang ada pada aplikasi. Halaman Algoritma ini diperuntukan sebagai bahan pengujian bahwa aplikasi yang dijalankan telah sesuai dengan metode yang telah dipakai sebagai alat bantu untuk menghitung kata yang diucapkan dengan kata yang telah ada sehingga jika mengucapkan sedikit kesalahan dengan nama surat yang diinginkan, tetap dapat membuka halaman surat $\mathrm{Al}$ Qur'an yang diinginkan.

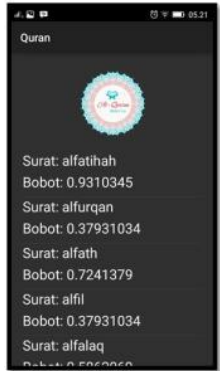

Gambar 6. halaman CBR

\subsection{Halaman Daftar Surat}

Halaman Daftar Surat merupakan halaman yang berisi tentang daftar nama surat yang terdapat pada Al Qur'an, sehingga pengguna bisa mengetahui surat apa saja yang terdapat pada $\mathrm{Al}$ Qur'an, hal ini juga berfungsi sebagai indikator nama surat yang dapat di panggil menggunakan perintah suara.

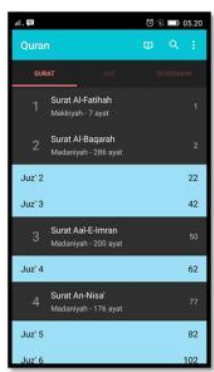

Gambar 7. Halaman Daftar Surat

\subsection{Halaman Surat}

Halaman Surat merupakan halaman yang terdapat didalam nama surat yang telah di ucapkan sebelumnya, halaman ini berisi beberapa halaman yang dapat dibuka menggunakan perintah suara. Sehingga memudahkan untuk penyandang disabilitas tangan dalam membaca Al Qur'an tiap halamannya.

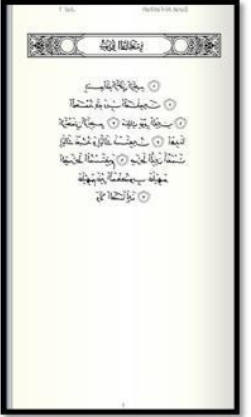

Gambar 8. Halaman surat yang dipanggil 


\section{Kesimpulan dan Saran \\ 4.1 Kesimpulan}

Berdasarkan hasil analisis yang telah diteliti, metode Case-Based Reasoning dapat membantu sistem dalam menghitung kesalahan kata yang diucapkan dengan kata yang terdapat di dalam sistem. Sehingga jika terjadi sedikit kesalahan didalamnya sistem akan mengetahui nama surat yang pengguna panggil dengan menghitung jarak terdekat antara kata yang diucapkan dengan nama surat yang ada pada sistem. Sistem ini dapat membantu penyandang disabilitas tangan dalam membaca kitab suci Al Qur'an tanpa memperhatikan aksen kata yang diucapkan. Hasil uji coba akurasi data menunjukan bahwa keakuratan sistem adalah $100 \%$ dari perbandingan antara 114 uji coba dari perhitungan manual dengan metode Case-Based Reasoning.

\subsection{Saran}

Setelah melalui tahap perencanaan, perancangan hingga pengujian, sistem yang dibuat belum sempurna dan masih dapat dikembangkan menjadi lebih baik lagi. Untuk itu saran pengembangan yang dapat diberikan adalah dengan menambahkan terjemahan menggunakan command voice dan menjadikan aplikasi ini menjadi offline. Sehingga dapat digunakan dengan mudah tanpa adanya koneksi yang stabil.

\section{Daftar Pustaka:}

Aingindra."Android"[Online]Tersedia:http://www. aingindra.com/android-adalah pengertianandroid-siste-operasi.html[16 Maret 2015]

Aldy,Mereya."Aplikasi Android" [Online] Tersedia: https://elib.unikom.ac.id [16 Maret 2015]

Benitoramio." Yuk, Merengkuh Tangan Penyandang Disabilitas" [Online] Tersedia:http://benitoramionugroho.blogpot.com/2012/05/yukmerengkuh-[16 Maret 2015]

Hildenbrand."Mengenal Android" [Online] Tersedia: http://www.androidcentral. com [16 Maret 2015]

Motohar. "command voice" [Online] Tersedia: https://mutohar.files.wordpress.com/2007/ 11/voice-recognition.pdf [15 januari 2016.

Octaviani,Fransica."Implementasi Case Based Reasoning Untuk Sistem Diagnosis Penyakit Anjing" [Online] Tersedia: http://ti.ukdw.ac.id/ojs/index.php/informatika/
article/viewFile/101/64 [30 mei 2016]

Rinoariffudin"Speec Recognition" [Online] Tersedia:https://rinoariffudin.wordpress.c om/2015/11/01/speec-recognition/ [22 Juni 2016]

Suryawan,Muji, Virtual Mouse Menggunakan Algoritma Haarcascade Dan Hough Transform Sebagai Media Interaksi Manusia Dengan Komputer Bagi Penyandang Disabilitas, 8(1), 2015, 55-72.

Wenda. "Speech recognition without Google dialog boxes" [Online] Tersedia: http://wenda.soso.io/questions/2272201/spee ch- recognition- without-google-dialogboxes [1 April 2015]

wikipedia."versi android"[Online] Tersedia: https://fr.wikipedia.org/wiki/Historique_d es_versions_d\%27Android(definisi android) [21 juni 2016] wordpress."API"[Online] Tersedia: https://ecoframeworkwordpress.com/2012/10/23/ apa-itu-googleapi [30 mei 2016.] 